\title{
Identity: A Cultural Perspective
}

\author{
Nicholas Surdel* \\ University of Florida, USA
}

Submission: November 10, 2018; Published: November 27, 2018

*Corresponding author: Nicholas Surdel, Researcher and Student at the University of Florida, USA

\begin{abstract}
Though highly stigmatized in the United States' sociocultural environment, "Generation Me" inevitably will be leading the world by the end of this century. The purpose of this article is to utilize existing literature in attempt to understand the roots of how their identity has and will continue to manifest in daily life. Through the lens of Dr. Marcia's ego-identity status theory, I will delve into the motivational roots of today's generation of developing professionals.
\end{abstract}

Keywords: Identity; Cultural; Sociocultural; Environment

\section{Opinion}

Who are you? Though this question seems simple, the syntax that ensues is anything but. The quantity of potential replies is limitless when considering the parameters of defining the self. In Westernized countries, such as the United States, responses typically consist of: titles (president, manager, doctor), professions (pediatrician, professional golfer, student), and relationships (wife of..., son of...). The jury is still out on whether this sense of individualistic identity is either symptomatic or resultant of, what contemporaries call: "Generation Me", whom are marked as tolerant, confident, open-minded, and ambitious, yet narcissistic, distrustful, anxious, and disengaged [1]. Whereas in traditional Eastern cultures, based on social identities influencers', responses tend to be more aligned with: kin (Wang family) and role (family elder) [2]. However, something that is consistent between both Western and Eastern cultures is a period of personal uncertainty.

Identity is defined as the fact of being who or what a person or thing is. According to one of the lead researchers on identity, James Marcia [3], one's identity status is quadfurcated into: diffusion, foreclosure, moratorium, and achievement. Inter-status examinations reveal a unique cultural discord between identity foreclosure and moratorium. Within the theory, to foreclose one's identity is to be committed to a path in the absence of an identity crisis. This, for instance, means that you want to be a blacksmith because you were raised in the profession - you do not know any other way. To possess identity moratorium, one must have explored various commitments but has yet to fully commit. A third-party utilitarian onlooker may argue that foreclosure is better because the individual is in a position of security and fiscal power, however, they may also argue that moratorium is better because the individual is in an advantageous intellectual position - setting the seeds for the future. This is where the cultural rift erupts.
In the United States, since the Baby Boomer generation, there has been a culture of simultaneous differentiation and conformity [4]. Denizens want to be different and special, yet they will concede all their beliefs to appear relatable and likable. This conformity breeds contempt and feelings of entitlement, "I deserve to do X because I have given up so much in my past." To me, this phenomenon is known in contemporary literature as licensing. Persons believe their "desirable" behavior justifies their "undesirable" behavior, in this case the desirable behavior is conformity and the undesirable are perceived selfishness. This environment bread Generation Me's recognition that they must redefine selfishness to permit the setting on one's own path to happiness.

Resultant of this recipe lies a distinct need to be different from their predecessors. Therefore, a member of Generation Me would view identity foreclosure as a life sentence - a fate worse than death - for you are performing the ultimate conforming act. So, what of identity moratorium? The average meritocratic American would argue that moratorium is merely a step towards the American Dream. Growing up, the American Dream is cited everywhere. When I say everywhere, I mean everywhere: even when making small talk with a waitress at your favorite restaurant, the topic of succeeding their current position; to elevate their current standard of living, consistently arises. So, it is not hard to imagine how a step towards such a galvanizing goal is regarded positively.

To drive the point home, I will provide some numbers... according to collegedata.com for the 2017-2018 academic year, the average in-state public college tuition cost is $\$ 25,290$ per year and the average private college tuition cost is $\$ 50,900$ per year. A conservatively estimated $75 \%$ of all college students either register as an "undeclared" major or change their major at some point in their collegiate career. This illustrates that the importance 


\section{Annals of Social Sciences \& Management studies}

of finding your niche in American society is so important that students will change their mind even after investing tens of thousands of dollars.

So, what are the implications of this? Well, the implications are that Generation Me inhabitants are scrutinizing their career path in hopes of enjoying the third of their life spent working. Based on the heaps of literature on motivation, we know that the more intrinsic motivation (by enjoying their work) the higher quality and quantity of work will be completed. Therefore, it is not too much of a stretch to argue that through these sociological mechanisms - we should be producing a more studious and dedicated workforce than ever before. So, what does this mean? This means that perhaps "Generation Me" is a misnomer. Perhaps we should relabel it "Generation Us" because it is saving us, as a collective, from another generation of artificial-selves that do what they must rather than what they want. I certainly know that I would rather have a dedicated doctor, who loves her job, performing my surgery than a dilapidated surgeon who is only working for the paycheck. So, I suppose, the only question remaining is: Who are you?

\section{References}

1. Twenge, JM (2014) Generation me: why today's young Americans are more confident, assertive, entitled and more miserable than ever before. Atria Paperback, New York, USA.

2. Hong, Chan, Chiu, Wong, Hansen, et al. (2003) How are social identities linked to self-conception and intergroup orientation? The moderating effect of implicit theories. Journal of Personality and Social Psychology 85(6): 1147-1160.

3. Marcia, JE (1966) Development and validation of ego-identity status. Journal of personality and social psychology 3(5): 551-558.

4. Twenge, JM, Campbell, WK, Freeman, et al. (2012) Generational differences in young adults' life goals, concern for others, and civic orientation, 1966-2009. Journal of Personality and Social Psychology 102: 1045-1062.

\begin{tabular}{l} 
Your next submission with Juniper Publishers \\
will reach you the below assets \\
- Quality Editorial service \\
- Swift Peer Review \\
- Reprints availability \\
- E-prints Service \\
- Manuscript Podcast for convenient understanding \\
- Global attainment for your research \\
- Manuscript accessibility in different formats \\
( Pdf, E-pub, Full Text, Audio) \\
- Unceasing customer service \\
Track the below URL for one-step submission \\
https://juniperpublishers.com/online-submission.php \\
\hline
\end{tabular}

